\title{
Potential prevention of diabetes and obesity by achieving macronutrient balance: a guide for diet and fast food
}

\author{
JAMES EL MACKINTOSH, ${ }^{1}$ JEMINIE PATEL MISTRY, ${ }^{2}$ SARAH N ALI, ${ }^{3}$ VINOD PATEL $^{1}$
}

\begin{abstract}
Protein is the most satiating macronutrient. Animal studies have indicated that there may be a discrete amount of protein that an individual seeks to consume each day. Given this to be true, a person will continue to eat until this amount of protein has been consumed. Once the target is met, hunger signals are switched off. By altering the proportion of protein in a diet, you can affect how many calories are required to meet this target. A diet with a protein content $>15 \%$ drives weight loss through the reduction of calories consumed to meet protein needs. We hypothesise that changing the proportion of calories from protein in a person's diet from $12 \%$ to $20 \%$ could alter their total intake by $1000 \mathrm{kcal}$ each day. This equates to a weight change of $0.9 \mathrm{~kg}$ each week. Maintaining a healthy weight is not as simple as changing a single variable. Eating habits in the UK are governed by a range of complex interdependent factors including hunger, emotions, cost, accessibility, education and culture. However, we suggest that by addressing satiety, and thereby hunger, we may remove a significant barrier for those trying to alter their diet for weight loss.

Br J Diabetes 2020;20:61-69
\end{abstract}

Key words: macronutrients, protein, weight loss, fast food, satiety

\section{Introduction}

The UK is undergoing an obesity epidemic. In England 64\% of adults are classified as overweight or obese. ${ }^{1}$ In 2017/18 there were 10,660 hospital admissions directly attributable to obesity and 711,000 admissions where obesity was a factor. ${ }^{2}$ It is estimated that the NHS spent $\mathrm{f} 6.1$ billion on overweight and obesity-related ill health in 2014-2015. ${ }^{3}$ This problem is widely acknowledged by healthcare professionals, government policy

Warwick Medical School, Warwick, UK

Dietetics, Queen Elizabeth Hospital, Birmingham, UK

Endocrinology Department, Royal Free Hospital, Hampstead, London, UK

Address for correspondence: Mr James EL Mackintosh Warwick Medical School, Gibbet Hill Road, Warwick CV4 7HL, UK E-mail: J.MacKintosh@warwick.ac.uk

https://doi.org/10.15277/bjd.2020.245 makers and the general public. However, obesity is still on the rise. If trends persist, one in three people in the UK will be obese and one in 10 will have type 2 diabetes (T2DM). ${ }^{4}$

Being overweight or obese is the main modifiable risk factor for developing diabetes. ${ }^{4}$ Furthermore, men with body mass index $(\mathrm{BMI}) \geq 35 \mathrm{~kg} / \mathrm{m}^{2}$ have a relative risk of developing T2DM 42.1 times greater than men with $\mathrm{BMI} \leq 23 \mathrm{~kg} / \mathrm{m}^{2} .^{5}$ Diabetes directly costs the UK $f 8.8$ billion a year. ${ }^{4}$ The annual spend on the treatment of obesity and diabetes is greater than the amount spent on the police, the fire service and the judicial system combined. ${ }^{3}$ Unfortunately, the factors affecting eating habits in the UK are numerous and complex. This makes it difficult to give advice that will work for the whole population. In a survey of over 3,000 people, respondents stated that two of the main difficulties in trying to eat more healthily was increased cost and time constraints. ${ }^{6}$

The impact of cost was further demonstrated in a systematic review showing a significant difference in fruit and vegetable consumption between socioeconomic groups, with those in the lowest group consuming the least. ${ }^{7}$

One study showed that distributing the same amount of energy over more meals throughout the day improved satiety. ${ }^{8}$ Another study, looking at meal duration, found the group having the longer meal felt fuller and less hungry. ${ }^{9}$ These results show how time constraints could impact food consumption.

Stress affects eating habits and is out of the control of the individual, as are cost and time constraints. One review found that stress increases the drive to eat higher calorie or more 'palatable' food via its interaction with central reward pathways. ${ }^{10}$

Current weight loss advice is to restrict calories consumed, for which there is strong research evidence. ${ }^{11-13}$ This is the foundation on which almost all 'weight loss diets' are based. Unfortunately, research has shown that people struggle to maintain successful weight loss over a long period of time. For example, in one study only $12 \%$ of the 192 participants maintained at least $75 \%$ of their weight loss three years later, and $40 \%$ gained more weight than they had originally lost. ${ }^{14}$

The biggest factor determining success of weight loss diets is sustainability (or can be thought of as compliance). ${ }^{15,16}$ "Adherence to a dietary weight loss intervention is strongly associated with weight loss success over the short and long term." 17

There has been a shift in culture accompanying the obesity crisis, which has seen fast food making up a larger proportion of the nation's diet. More than one-quarter (27.1\%) of adults and 
one-fifth of children eat food from out-of-home food outlets at least once a week. ${ }^{3}$ In England there are 88 fast food outlets per 100,000 people, with higher ratios correlating with more deprived areas. $^{3}$

This paper proposes a hypothetical model for weight loss that focuses on manipulating the proportion of calories from protein in a diet. We will discuss the evidence supporting the model and will demonstrate that it can be successfully applied to fast food.

\section{Background}

\section{Satiety}

In order to lose weight, a person must reduce his/her calorie intake to below their energy expenditure. This must be sustained over a long period of time. Adherence to weight loss diets is typically driven by hunger. By choosing foods that are more satiating, it is possible to improve adherence to diets and weight loss. This is possible as isoenergetic servings of different foods differ greatly in their satiating capacities. ${ }^{18}$ Protein, fibre and water content correlate positively with satiety, as is the weight of the serving of food, whereas palatability and fat content correlate negatively with satiety. The food with the highest satiety rating in the study, boiled potatoes, has a high fibre and water content, low energy density (increasing serving weight) and low palatability and fat content. It has been further demonstrated that increasing the volume of food independently of energy content increases satiety. ${ }^{19}$ Use of a higher protein diet has been shown to improve perceptions of satiety and pleasure during energy restriction. ${ }^{20}$

Protein is the macronutrient with the greatest positive effect on satiety. A high protein diet, compared with an average protein diet, fed at energy balance for 4 days increased 24-hour satiety, thermogenesis, sleeping metabolic rate, protein balance and fat oxidation. ${ }^{21}$ High protein diets have been shown to be better than high carbohydrate diets at producing a feeling of fullness. ${ }^{22}$

Research has shown that increasing protein, water, fibre and food weight correlated with an increase in satiety when controlled for energy content, ${ }^{18}$ whereas fat content and palatability correlated negatively with satiety. A greater feeling of fullness can be achieved by reducing the energy density of a given meal. ${ }^{23}$ This can be thought of as less calories in more physical food. This can be achieved by choosing food with more fibre, which adds bulk and weight to a meal. ${ }^{23} \mathrm{~A}$ similar effect has been observed by consuming food with a greater water content. ${ }^{24}$

Protein-rich diets have the additional benefit of preserving muscle mass while promoting weight loss from adipose tissue. This increases baseline energy expenditure. ${ }^{25,26}$ Consuming a higher protein diet before becoming obese helped women preserve lean body mass during weight loss. ${ }^{20}$

Protein increases long-term diet adherence by improving satiety. Following a protein-deficit food intake, subjects in one study were found to change their food preferences to restore adequate protein stores. When offered the choice of foods after the deficit, they showed a preference for protein-rich options. ${ }^{27}$

\section{Protein effects in ad libitum diets}

There have been many studies exploring the effect of increasing protein in ad libitum dieting. This is where the subject can eat as much as they like, within the parameters of the prescribed diet. These studies demonstrate the effect of protein on hunger and consumption. This is the key underlying principle for our weight loss model. It has been shown that individuals under-ate relative to energy balance from diets containing a higher proportion of calories from protein. ${ }^{28}$ Despite a lower energy intake, sustained satiety has been achieved following a diet with a higher absolute protein consumption. ${ }^{29}$

Isoenergetic high protein diets were shown to make no difference to weight loss when compared with isoenergetic lower protein diets, but showed a significant difference in ad libitum dieting. ${ }^{30}$ This result has been repeated in other studies which found that higher protein diets increased weight loss in ad libitum dieting. ${ }^{31}$ Furthermore, a higher protein content of an ad libitum diet improved weight loss maintenance in overweight and obese adults over 12 months. ${ }^{32}$

One study concluded that low-fat, energy-restricted diets of varying protein content (15\% or $30 \%$ energy) promoted healthful weight loss, but diet satisfaction was greater in those consuming the high protein diet. ${ }^{33}$

An ad libitum diet with high protein and fibre content can improve fullness, thereby reducing total consumption of calories. The ad libitum element should provide an improvement to palatability ${ }^{27}$ and flexibility due to the nature of ad libitum dieting.

\section{Protein intake target}

Animal studies have shown that evolution of their nutritional intake target reflects the composition of their natural diet. ${ }^{34,35}$ Further research demonstrates that humans have a set appetite for protein. ${ }^{36}$ In a more practical example, a high protein diet reduced subjects' preference for protein-containing foods, whereas high carbohydrates did not have the same effect. ${ }^{22}$ This shows that protein consumption regulates appetite to a greater extent than carbohydrates. On a population level, the protein content of diets varies significantly less than consumption of carbohydrate or fat, indicating that protein consumption is more tightly regulated than intake of carbohydrates or fat. ${ }^{37}$ Increasing protein intake has been shown to reduce hunger and food consumption later in the day. ${ }^{22,38}$

Only one study has addressed finding an actual figure for the target protein intake. The results were that, when a diet contained a lower ratio of protein than $12-15 \%$ of total calories, the response in the subjects was to consume food until the target amount of protein was hit. This led to overconsumption of fat and carbohydrates, and therefore calories. ${ }^{39}$ In another study, lowering protein from $15 \%$ to $10 \%$ increased total energy intake. However, increasing protein from $15 \%$ to $25 \%$ did not have a significant effect on total energy intake. ${ }^{40}$ These results form the basis for the $15 \%$ protein target in the model.

\section{Protein: additional benefits}

Increasing protein intake has many benefits in addition to increasing satiety. Studies have shown that, during energy-restricted diets, higher protein provides modest benefits for reduction in 
body weight, fat mass and mitigation of reductions in free fat mass and resting energy expenditure. ${ }^{41}$

Short-term high protein weight loss diets have been shown to have beneficial effects on total cholesterol and triacylglycerol in overweight and obese subjects and achieved greater weight loss and better lipid results in subjects at increased risk of cardiovascular disease. ${ }^{42}$

A realistic high protein weight-reducing diet was associated with greater fat loss and lower blood pressure than a high carbohydrate, high fibre diet in high-risk overweight and obese women. ${ }^{43}$

The effect of high protein and low glycaemic index was additive on weight loss and maintenance, and the combination was successful in preventing weight regain and reducing the drop-out rate among adults after an $11 \mathrm{~kg}$ weight loss. This diet also reduced body fat and the prevalence of being overweight or obese among their children, and had consistent beneficial effects on blood pressure, blood lipids and inflammation. ${ }^{44}$

\section{Protein: potential harmful effects}

Along with the benefits of high protein diets, one must also consider the potential harmful effects. There have been two recent epidemiological studies that have shown significant associations between high protein diets and decline in kidney function. ${ }^{45,46} \mathrm{~A}$ further large cohort study performed in healthy adults showed a significantly greater risk of chronic kidney disease in participants who consumed the most protein compared with those consuming the least. ${ }^{47}$

In a systematic review of 111 studies focused on health outcomes in high and low protein diets, it was observed that adverse gastrointestinal effects were more common in people following a high protein diet. ${ }^{48}$

However, these potential negative effects must be weighed against the benefits of sustainable weight loss for health. This needs to be done on an individualised basis, considering a person's underlying health conditions and their risk factors for obesity and weight-related morbidity and mortality.

\section{Box 1 Definitions}

$1 \mathrm{kcal}$ : energy needed to raise the temperature of $1 \mathrm{~kg}$ of water through $1^{\circ} \mathrm{C}$

Macronutrients: energy-providing nutrients; protein, carbohydrates and fat

Protein: chain of amino acids, build muscle, cell signalling, immune function and enzymes, most satiating, 4 kcal/g, meat/poultry/beans/ fish/eggs, most tightly regulated macronutrient

Carbohydrates: sugars/starches/fibre, source of readily available energy (usually glucose) or stored as glycogen in liver and muscles,49 4 kcal/g, grains/potatoes/vegetables/rice/pasta

Fat: lipids, required for hormone production, absorption of lipid-soluble vitamins (ADEK), body temperature regulation, $9 \mathrm{kcal} / \mathrm{g}$,

oils/butter/nuts/avocado

Junk food: food that increases calorie intake without meaningfully contributing to nutritional targets. Individualise to patient - weight, aspirations, season, activity level

Healthy food: meeting/exceeding nutritional targets within given calorie constraints

Junk calories: extra daily calories consumed to meet protein target

\section{Model}

We are proposing a model for weight loss based on the principle that the human body has a drive to consume a discrete amount of protein each day. Driven by hunger, a person will keep eating until this target is met. Once the target is reached, appetite is reduced. Therefore, a diet where protein makes up $15 \%$ or more of the total calories will reach the protein threshold sooner and may avoid overconsumption of fat and carbohydrates.

\section{Outlining the model using an illustrative example}

Using the Mifflin-St Jeor equation, ${ }^{50}$ a 40 -year-old male who is $170 \mathrm{~cm}$ tall, weighs $80 \mathrm{~kg}$ and has a sedentary lifestyle requires $2000 \mathrm{kcal} /$ day to maintain his body weight. Note that this is an illustrative example used to make the numbers easier to follow. One can use the Mifflin-St Jeor equation ${ }^{50}$ to calculate personalised calorie requirements, to which the below model can be applied.

Table 1 Calories/g of macronutrients (Box 1)

\begin{tabular}{ll}
\hline Nutrient & kcal/g \\
Carbohydrate & 4 \\
Protein & 4 \\
Fat & 9 \\
Alcohol & 7
\end{tabular}

Protein requirements $=15 \%$ of daily calories $=15 \% \times 2000 \mathrm{kcal}$ $=300 \mathrm{kcal}=4 \mathrm{kcal} / \mathrm{g} \times 75 \mathrm{~g}$ protein (Table 1)

Protein requirement $=75 \mathrm{~g}$

Patient eats pizza and chips where only $12 \%$ of calories come from protein. Patient consumes $2000 \mathrm{kcal}$. Calorie requirements are met.

$240 \mathrm{kcal}$ from protein $(12 \%$ of 2000$) \rightarrow 60 \mathrm{~g}$ protein (Table 1) Protein deficit of $15 \mathrm{~g} \mathrm{(75} \mathrm{g-60} \mathrm{g)} \rightarrow$ Patient needs to consume $15 \mathrm{~g}$ of extra protein.

Following the same macros (12\% protein), $15 \mathrm{~g}$ of protein will be consumed through an additional $15 \mathrm{~g} \times 4 \mathrm{~g} / \mathrm{kcal} / 12 \%=500$ $\mathrm{kcal}$ (Table 1). By consuming an additional $500 \mathrm{kcal}$ each day, the patient will gain $0.45 \mathrm{~kg} /$ week. $^{5}$

Now consider the same patient on a new diet with $20 \%$ of calories from protein. In order to consume the $75 \mathrm{~g}$ protein target, the patient must consume $75 \mathrm{~g} \times 4 \mathrm{kcal} / \mathrm{g} / 20 \%=1500 \mathrm{kcal}$ (Table 1). Once the target is hit, the appetite is suppressed reducing further consumption. This is a deficit of $500 \mathrm{kcal}$ which would result in a loss of $0.45 \mathrm{~kg} /$ week. $^{5}$

\section{Method of application to fast food}

In the UK the five most popular fast food restaurants are McDonald's, KFC, Subway, Burger King and Pizza Hut. ${ }^{51}$ We chose popular meals from each and recorded calories, macronutrient content, fibre content and price. From these data we calculated the percentage of daily calorie requirements, percentage of calories from each macronutrient, fullness factor, ${ }^{52}$ junk calories and projected weight loss. The calculations are detailed in Table 2. 
Table 2 Criteria

\begin{tabular}{|c|c|}
\hline Criteria & Description \\
\hline$\%$ kcal daily requirement & Proportion of total daily calories (2000 kcal) that meal makes up, expressed as a percentage to 1 decimal place \\
\hline $\mathrm{P} / \mathrm{C} / \mathrm{F}(\mathrm{g})$ & Protein/Carbohydrate/Fat content of the meal given in grams to 1 decimal place (Box 1) \\
\hline$\%$ kcal from P/C/F & $\begin{array}{l}\text { Proportion of the meal's total calories that are made up from each of protein, carbohydrates and fat (given that } \\
\text { protein and carbohydrates have } 4 \mathrm{kcal} / \mathrm{g} \text { and fat has } 9 \mathrm{kcal} / \mathrm{g} \text { ) }\end{array}$ \\
\hline Fullness factor & $\begin{array}{l}\text { A measure of satiety per calorie based on Holt's } 1995 \text { study. Value between } 0.5 \text { and 5.0, where a higher value } \\
\text { indicates a greater level of satiety per calorie } 18,52 \text { (see Appendix online at www.bjd-abcd.com) }\end{array}$ \\
\hline Weight (g) & Weight of meal, used as proxy for volume ${ }^{18,53-57}$ \\
\hline Fibre $(g)$ & Fibre content in grams to 1 decimal place $53-57$ \\
\hline Junk calories & $\begin{array}{l}\text { Compensatory calories: the additional calories consumed above a person's daily maintenance in order to hit their } \\
\text { protein target (for these examples, } 15 \% \text { of } 2000 \mathrm{kcal} / 4 \mathrm{kcal} / \mathrm{g} \text { of protein }=75 \mathrm{~g} \text { ), given that a person eats the } \\
\text { given meal and the rest of their diet has a protein content of } 15 \%\end{array}$ \\
\hline Red & $\begin{array}{l}\text { Protein content }<12.5 \% \\
\text { Hard to compensate for and causes over consumption of fat/carbohydrates }\end{array}$ \\
\hline Amber & $\begin{array}{l}\text { Protein content } 12.5-15.0 \% \\
\text { Easier to compensate for }\end{array}$ \\
\hline Green & $\begin{array}{l}\text { Protein content }>15 \% \\
\text { Causes under consumption of fat/carbohydrates }\end{array}$ \\
\hline
\end{tabular}

We then made progressive substitutions to each meal aiming to reduce calories, increase protein content and maintain cost neutrality.

\section{Big Mac meal analysis}

The standard Big Mac meal comprises a Big Mac burger, medium fries and a medium soft drink. In the first case the drink selected is regular coke. This represents a popular choice at McDonald's across the UK (Table 3).

Table 3 Big Mac meal analysis

\begin{tabular}{|c|c|c|c|c|c|c|c|c|c|c|c|c|c|c|}
\hline Meal & $\begin{array}{l}\text { Total } \\
\text { kcal }\end{array}$ & $\begin{array}{l}\% \text { kcal } \\
\text { daily } \\
\text { requirement }\end{array}$ & $\mathrm{P} / \mathrm{C} / \mathrm{F}$ & $=(g)$ & & $\begin{array}{l}\% \text { of } \\
\text { from }\end{array}$ & $\begin{array}{l}\text { kcal } \\
\mathrm{P} / \mathrm{C} / \mathrm{F}\end{array}$ & & Price & $\begin{array}{l}\text { Fullness } \\
\text { factor }\end{array}$ & $\begin{array}{l}\text { Weight } \\
\text { (g) }\end{array}$ & $\begin{array}{l}\text { Fibre } \\
\text { (g) }\end{array}$ & $\begin{array}{l}\text { Junk } \\
\text { calories }\end{array}$ & $\begin{array}{l}\text { Weight } \\
\text { change } \\
\text { kg/week }\end{array}$ \\
\hline $\begin{array}{l}\text { Big Mac + Fries } \\
\text { (medium) + } \\
\text { Coke (medium) }\end{array}$ & 1015 & $50.8 \%$ & 29.3 & 127.0 & 42.0 & 11.7 & 50.6 & 37.7 & $£ 4.79$ & 2.00 & 591 & 7.2 & 234 & 0.21 \\
\hline $\begin{array}{l}\text { Option 1: } \\
\text { Big Mac + Fries } \\
\text { + Diet Drink }\end{array}$ & 846 & $42.3 \%$ & 29.3 & 85.0 & 42.0 & 14.0 & 40.7 & 45.3 & f4.79 & 2.15 & 591 & 7.2 & 65 & 0.06 \\
\hline $\begin{array}{l}\text { Option 2: } \\
\text { Big Mac + } \\
\text { side salad + } \\
\text { water }\end{array}$ & 526 & $26.3 \%$ & 26.9 & 45.1 & 25.5 & 20.8 & 34.9 & 44.3 & $£ 4.79$ & 2.29 & 377 & 4.7 & -191 & -0.17 \\
\hline $\begin{array}{l}\text { Option 3: } \\
\text { Big Mac - } \\
\text { bun + side } \\
\text { salad + water }\end{array}$ & 313 & $15.7 \%$ & 19.9 & 7.1 & 22.5 & 25.6 & 9.1 & 65.2 & $\mathrm{f} 4.79$ & 2.49 & 276 & 2.1 & -218 & -0.20 \\
\hline $\begin{array}{l}\text { Option 4: } \\
2 x \text { Double } \\
\text { cheeseburger } \\
+ \text { water }\end{array}$ & 890 & $44.5 \%$ & 52.0 & 64.0 & 46.0 & 23.7 & 29.2 & 47.2 & $£ 4.47$ & 2.30 & 596 & 4.8 & -497 & -0.99 \\
\hline
\end{tabular}


The meal is very calorific and makes up over half of the 2000 kcal daily intake. It has a protein content of $11.7 \%$ which falls short of the $15 \%$ target. This results in a projected 234 junk calories. If consumed daily, the resultant compensatory calorie intake from this meal would increase a person's weight by $0.21 \mathrm{~kg} /$ week. This can be extrapolated to a weight gain of $11 \mathrm{~kg}$ per year.

The first option for making a better choice than the standard meal changes the soft drink to a diet variety. This reduces the total calories of the meal through a reduction in carbohydrates. As the protein content remains constant alongside the reduction in calories, the proportion of calories from protein is greater than that of the original meal. As the protein content is below the $15 \%$ target, there are 65 junk calories and a gain of $0.06 \mathrm{~kg} / \mathrm{week}$. The fullness factor increases from 2.00 to $2.15^{*}$. As the fibre and weight remain constant, the improvement in satiety per calorie is entirely from the increased protein content. This shows a significant improvement from the original meal without greatly altering palatability.

Option 2 switches the fries for a side salad and the diet soft drink for water at no extra cost. Changing to water does not alter the nutritional data in the table. However, it is likely a better choice as diet soda consumption is associated with a significantly greater risk of developing T2DM. ${ }^{60}$ The side salad reduces the total calories, absolute protein content and fibre content. As the calories are reduced to a greater degree than the protein, the percentage of calories from protein increases to $20.8 \%$. This, combined with the dramatic drop in calories, results in a projected weight loss of $0.17 \mathrm{~kg} /$ week, or $9 \mathrm{~kg}$ per year.

Option 3 removes the bun. This reduces the carbohydrates and calories, which results in an increased percentage of calories from protein. Option 3 is the lowest calorie meal considered. It has less than a third of the calories in the standard meal. There is an increase in fullness factor despite the reduction in fibre and meal weight. This is due to an increase in protein. Option 3 has a projected reduction in junk calories of $218 \mathrm{kcal}$ and a weight loss of over $10 \mathrm{~kg}$ per year. While option 3 has a higher fullness factor than other options, it is unlikely to be more filling in a direct comparison due to the dramatically lower calories and meal volume.

Option 4 explores an alternative to the Big Mac meal. In this case we have stuck to a beef burger theme to provide a similar palatability. This option costs $32 p$ less than the other options. Option 4 is lower calorie than the standard meal, and similar calories to option 1 . The meal contains $52 \mathrm{~g}$ of protein, which is double the percentage of calories from protein in the standard meal. This reduces junk calories by $497 \mathrm{kcal}$ and projects a weight loss of $0.99 \mathrm{~kg} /$ week if this meal is consumed daily.

The trend through options 1-3 show that, for the same cost, a person could purchase meals of lower calories, higher protein and higher satiety. Across the four options the junk calories decrease and projected weight loss increases. This shows that it is possible to order fast food as part of a diet for weight loss.

\section{Subway salads and best 6 inch sub}

Three of Subway's salads were compared with the 6 inch sub (Table 4), which was found to have the most favourable macros for weight loss in the analysis tables for choice of bread, meat, cheese and sauce (see Appendix online at www.bjd-abcd.com). Subway offers all 6 inch subs as a salad, which is also included in the table.

All options are above the $15 \%$ protein target - in fact, over twice that. As a result, all options promote weight loss. The largest projected weight loss is seen in the options with the most calories. This demonstrates that eating more of one's daily calories from healthy sources yields a greater benefit.

Table 4 Subway salads and best 6 inch sub

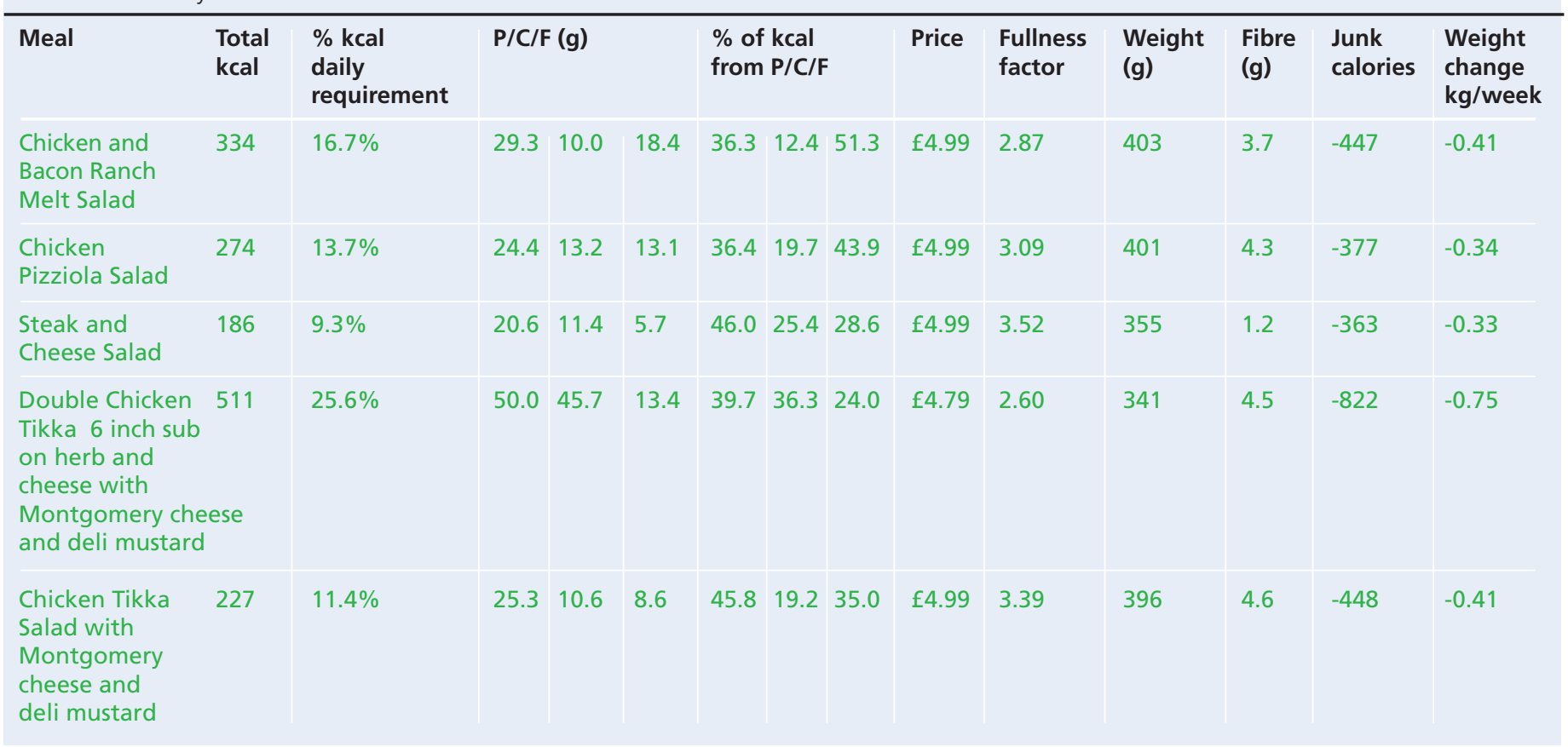


Options from Subway are appropriate for those with a lower daily calorie target. This includes patients who are of low weight, shorter stature and young women. The options all have a high fullness factor relative to other fast food. However, as these options are low calorie, they may not be more filling than a $1000 \mathrm{kcal}$ Big Mac meal. When combined with a $250 \mathrm{ml}$ bottle of water, the weight for these options ranges from $591 \mathrm{~g}$ to $653 \mathrm{~g}$. A Big Mac standard meal weighs $591 \mathrm{~g}$. Using weight as a proxy for volume, there is an argument for similar fullness.

The salads on offer have a high protein content and a lower calorie cost. They are also incredibly filling due to their volume. The model shows that the double meat 6 inch sub is a better option for projected weight loss. However, if price were not an issue, you could fit 2-3 of the salads into the same number of calories. This would increase satiety and reduce daily calorie intake.

\section{Discussion}

Adherence to a diet for weight loss is often made difficult if it prevents individuals from eating out or hampers the social aspect of eating. The application of this model to fast food demonstrates that it has the required flexibility and sustainability to be successful.

Cost is often a barrier to patients looking to improve their diet. ${ }^{6}$ By maintaining cost neutrality throughout, the analysis shows the potential accessibility of the model. Successful application of this model to fast food demonstrates the need to re-evaluate the definition of junk food and gives physicians a broader tool to advise on healthy eating (Box 1).

In one survey of over 1,000 people, $69 \%$ had eaten out at some point in the last seven days. However, $79 \%$ of meals and snacks were eaten at home. ${ }^{6}$ While the above results analyse food from fast food restaurants, the same principles can be successfully applied to meals eaten at home. By prioritising the portion size of protein and fibrous vegetables over carbohydrates and fats, patients may be able to increase their fullness and decrease their calorie intake.

Secondly, micronutrient deficiencies can develop despite eating a healthy balance of macronutrients.

Figure 1. Square Meals model

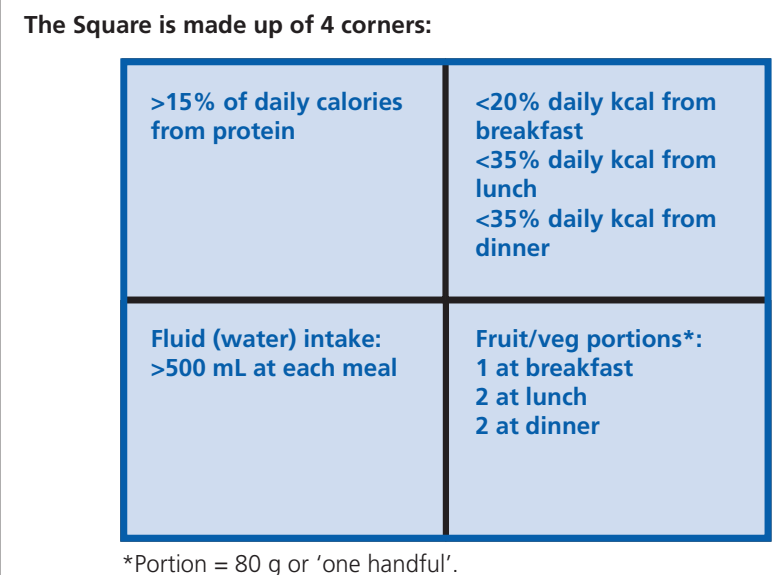

We have taken our model and have modified it to address some of the above issues. We have named it the 'Square Meals' model, which is shown in Figure 1 and is discussed below.

Aim for five portions of fruit and vegetables a day. ${ }^{61}$ This will reduce the likelihood of developing a micronutrient deficiency.

Water recommendation from the NHS is 6-8 glasses each day. ${ }^{62}$ This is approximately $1500-2000 \mathrm{~mL}$. The benefits of drinking more water include improved cognitive and physical performance, digestive health and avoiding the negative effects of dehydration. ${ }^{63}$

The square increases the satiety, hydration and nutrient intake of a diet. It reduces overconsumption of calories each day using the previous model. By setting calorie limits per meal, it improves portion control (Table 5).

Table 5 Colour coding reference ranges

\begin{tabular}{lllll}
\hline Meal & $\begin{array}{l}\text { \% kcal } \\
\text { daily } \\
\text { requirement }\end{array}$ & $\begin{array}{l}\text { \% of } \\
\text { calories } \\
\text { from } \\
\text { protein }\end{array}$ & $\begin{array}{l}\text { Fluid } \\
\text { intake } \\
(\mathbf{m L})\end{array}$ & $\begin{array}{l}\text { Portion of } \\
\text { fruit or } \\
\text { vegetables }\end{array}$ \\
\hline Red & $>45 \%$ & $<12.5 \%$ & $<100$ & 0 \\
\hline Amber & $35-45 \%$ & $12.5-15.0 \%$ & $100-500$ & 1 \\
\hline Green & $<35 \%$ & $>15.0 \%$ & $>500$ & 2 \\
\hline
\end{tabular}

\section{Square Meals applied}

Table 6 shows that the options discussed fail to meet the square meal targets for fluid intake and portions of fruit and vegetables

Table 6 Application of Square Meals model to Big Mac meal analysis

\begin{tabular}{|c|c|c|c|c|}
\hline Meal & $\begin{array}{l}\% \text { kcal } \\
\text { daily } \\
\text { requirement }\end{array}$ & $\begin{array}{l}\% \text { of } \\
\text { calories } \\
\text { from } \\
\text { protein }\end{array}$ & $\begin{array}{l}\text { Fluid } \\
\text { intake } \\
(\mathrm{mL})\end{array}$ & $\begin{array}{l}\text { Portion of } \\
\text { fruit or } \\
\text { vegetables }\end{array}$ \\
\hline $\begin{array}{l}\text { Big Mac + } \\
\text { Fries (medium) } \\
\text { + Coke (medium) }\end{array}$ & $50.8 \%$ & $11.7 \%$ & 250 & 0 \\
\hline $\begin{array}{l}\text { Option 1: } \\
\text { Big Mac + } \\
\text { Fries + } \\
\text { Diet Drink }\end{array}$ & $42.3 \%$ & $14.0 \%$ & 250 & 0 \\
\hline $\begin{array}{l}\text { Option 2: } \\
\text { Big Mac + } \\
\text { side salad + } \\
\text { water }\end{array}$ & $26.3 \%$ & $20.8 \%$ & 250 & 1 \\
\hline $\begin{array}{l}\text { Option 3: } \\
\text { Big Mac - } \\
\text { bun + } \\
\text { side salad + water }\end{array}$ & $15.7 \%$ & $25.6 \%$ & 250 & 1 \\
\hline $\begin{array}{l}\text { Option 4: } \\
\text { 2x Double } \\
\text { cheeseburger + } \\
\text { water }\end{array}$ & $44.5 \%$ & $23.7 \%$ & 250 & 0 \\
\hline
\end{tabular}


Table 7 Application of Square Meals model to Subway salads and best 6 inch sub

\begin{tabular}{lllll}
\hline Meal & $\begin{array}{l}\text { \% kcal } \\
\text { daily } \\
\text { requirement }\end{array}$ & $\begin{array}{l}\text { \% of } \\
\text { calories } \\
\text { from } \\
\text { protein }\end{array}$ & $\begin{array}{l}\text { Fluid } \\
\text { intake } \\
(\mathbf{m L})\end{array}$ & $\begin{array}{l}\text { Portion of } \\
\text { fruit or } \\
\text { vegetables }\end{array}$ \\
$\begin{array}{l}\text { Chicken and Bacon } \\
\text { Ranch Melt Salad }\end{array}$ & $16.7 \%$ & $36.3 \%$ & 250 & 2 \\
$\begin{array}{l}\text { Chicken Pizziola } \\
\text { Salad }\end{array}$ & $13.7 \%$ & $36.4 \%$ & 250 & 2 \\
$\begin{array}{l}\text { Steak and Cheese } \\
\text { Salad }\end{array}$ & $9.3 \%$ & $46.0 \%$ & 250 & 2 \\
$\begin{array}{l}\text { Double Chicken } \\
\text { Tikka } 6 \text { inch sub } \\
\text { on herb and cheese } \\
\text { with Montgomery } \\
\text { cheese and } \\
\text { deli mustard }\end{array}$ & $25.6 \%$ & $39.7 \%$ & 250 & 1 \\
$\begin{array}{l}\text { Chicken Tikka } \\
\text { Salad with } \\
\text { Montgomery } \\
\text { cheese and } \\
\text { deli mustard }\end{array}$ & $11.4 \%$ & & & \\
\hline
\end{tabular}

as set out in Figure 1. Comparing Table 7 to Table 6 indicates that Subway salads are a better option than a Big Mac meal in meeting targets for fruit and vegetable consumption. However, once again the fluid targets are not adequately met.

To address this, restaurants could incorporate fruit and vegetables into their reduced-price meal combinations. To meet fluid intake targets, patients should take it upon themselves to carry water with them. If restaurants were to provide customers with free tap water, this would help their customers hit their hydration targets.

The percentage of a person's daily calorie requirement will vary between individuals. This depends on height, weight, age and activity level.50 The figures in the tables are based on a daily requirement of $2000 \mathrm{kcal}$. The calorie targets for example patients that make meals $<35 \%$ of total intake are shown in Table 8 .

The Mifflin-St Jeor Equation calculates the basal metabolic rate (BMR) for ages 19-78:50

Men: $\mathrm{BMR}=10 \times$ weight $(\mathrm{kg})+6.25 \times$ height $(\mathrm{cm})-$

$5 x$ age $(y)+5$

Women: $\mathrm{BMR}=10 \times$ weight $(\mathrm{kg})+6.25 \times$ height $(\mathrm{cm})-$

$5 \mathrm{x}$ age $(\mathrm{y})-161$

To calculate the total calories a person burns in a day, the BMR should be multiplied by the activity factor, as shown in Table 9.50

Further discussion needs to be had concerning the inclusion of 'calories from protein' on food labelling and how best to approach this. It could be presented as a percentage of a target value as this has been shown to be an effective strategy. ${ }^{64} \mathrm{How}$ ever, there needs to be careful thought around implementing this, such that it has high impact and provides clear guidance that can be applied on an individual level.

Looking ahead it may be useful to produce a 'satiety index', not dissimilar to that described by Holt et al for common meals and snacks. ${ }^{18}$ This may give patients looking to lose weight an accessible tool for making better choices about their diet. Trialling this in the form of a patient leaflet may provide useful insight and provoke discussion that develops these ideas further.

Table 8 Examples of calorie targets to make meals $<35 \%$ of total intake

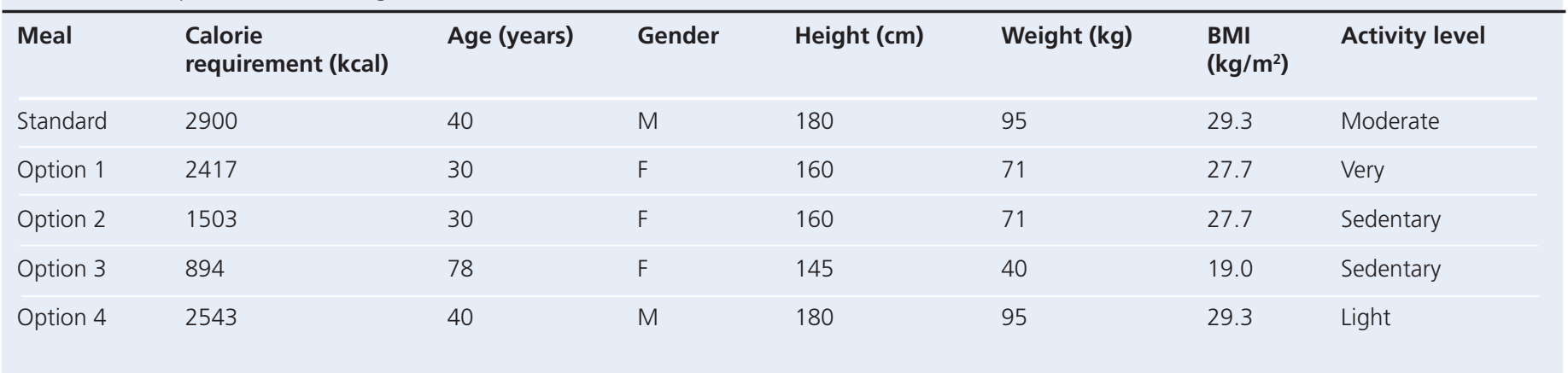

Table 9 Calculation of total calories burnt per day

\begin{tabular}{lll}
\hline Activity level & Description & Multiplier \\
Sedentary & You work at a desk job and do very little exercise or housework & 1.200 \\
Lightly active & You go for long walks 1-3 days per week or do housework like cleaning and gardening & 1.375 \\
Moderately active & You're moving most of the day and/or exercise with a moderate amount of effort 3-5 days of the week & 1.550 \\
Very active & You're vigorously exercising or playing sports most days & 1.725
\end{tabular}




\section{Key messages}

- High protein diets improve satiety and improve adherence to energy restricted diets

- Aim to consume at least $15 \%$ of daily calories from protein

- If you are willing to change the choices that you make, it is possible to eat out at fast food restaurants and lose weight, without spending more

- The manipulation of macronutrient intake is a good starting point to develop flexible sustainable diets for weight loss. However, eating for optimal health is ultimately more complicated than this

\section{Conflict of interest None. Funding None.}

\section{References}

1. GOV.UK. Health Survey for England 2017. [Internet]. 2019 (accessed 25 November 2019). Available from: https://www.gov.uk/government/statistics/health-survey-for-england-2017

2. NHS Digital. Statistics on Obesity, Physical Activity and Diet, England, 2019. [Internet]. 2019 (accessed 25 November 2019). Available from: https://digital.nhs.uk/data-and-information/publications/statistical/statistics-on-obesity-physical-activity-and-diet/statistics-on-obesity-physical-activity-and-diet-england-2019

3. GOV.UK. Health matters: obesity and the food environment [Internet]. 2019 (accessed 25 November 2019). Available from: https://www.gov.uk/ government/publications/health-matters-obesity-and-the-food-environment/health-matters-obesity-and-the-food-environment--2

4. GOV.UK. Health matters: preventing type 2 diabetes [Internet]. 2019 (accessed 25 November 2019). Available from: https://www.gov.uk/government/publications/health-matters-preventing-type-2-diabetes/health-matt ers-preventing-type-2-diabetes

5. Wishnofsky M. Caloric equivalents of gained or lost weight. Am J Clin Nutr 1958;6:542-6.

6. Prior G, Hall L, Morris S, Draper A. Exploring food attitudes and behaviours in the UK: findings from the Food and You Survey 2010. Food Standards Agency, 2011:6-9.

7. De Irala-Estevez J, Groth M, Johansson L, et al. A systematic review of socioeconomic differences in food habits in Europe: consumption of fruit and vegetables. Eur J Clin Nutr 2000;54:706-14. https://doi.org/10.1038/sj.ejcn.1601080

8. Smeets AJ, Westerterp-Plantenga MS. Acute effects on metabolism and appetite profile of one meal difference in the lower range of meal frequency. Br J Nutr 2008;99:1316-21. https://doi.org/10.1017/S0007114507877646

9. Angelopoulos T, Kokkinos A, Liaskos C, et al. The effect of slow spaced eating on hunger and satiety in overweight and obese patients with type 2 diabetes mellitus. BMJ Open Diabetes Res Care 2014;2(1):e000013. https://doi.org/10.1136/bmjdrc-2013-000013

10. Sominsky L, Spencer SJ. Eating behavior and stress: a pathway to obesity. Front Psychol 2014;5:434. https://doi.org/10.3389/fpsyg.2014.00434

11. Ravussin E, Redman LM, Rochon J, et al. A 2-year randomized controlled trial of human caloric restriction: feasibility and effects on predictors of health span and longevity. J Gerontol A Biol Sci Med Sci 2015;70:1097104. https://doi.org/10.1093/gerona/glv057

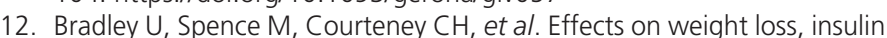
resistance, and cardiovascular risk: a randomized control trial. Diabetes 2009:58:2741-8. https://doi.org/10.2337/db09-0098

13. Wadden TA. Treatment of obesity by moderate and severe caloric restric- tion. Results of clinical research trials. Ann Intern Med 1993;119(7 Pt 2):688-93. https://doi.org/10.7326/0003-4819-119-7_part_2-19931001100012

14. Grodstein F, Levine R, Troy L, et al. Three-year follow-up of participants in a commercial weight loss program. Can you keep it off? Arch Intern Med 1996:156:1302-6.

15. Dansinger M, Gleason JA, Griffith JL, Selker HP, Schaefer EJ. Comparison of the Atkins, Ornish, Weight Watchers, and Zone diets for weight loss and heart disease risk reduction: a randomized trial. JAMA 2005;293: 43-53. https://doi.org/10.1001/jama.293.1.43

16. Alhassan S, Kim S, Bersamin A, King AC, Gardner CD. Dietary adherence and weight loss success among overweight women: results from the $A$ to Z weight loss study. Int J Obesity 2008;32:985-91. https://doi.org/10.1038/ijo.2008.8

17. Gibson A, Sainsbury A. Strategies to improve adherence to dietary weight loss interventions in research and real-world settings. Behav Sci (Basel) 2017;7:E44. https://doi.org/10.3390/bs7030044

18. Holt S, Miller J, Petocz P, Farmakalidis E. A satiety index of common foods. Eur J Clin Nutr 1995;49:675-90.

19. Rolls $B$, Bell $E$, Waugh $B$. Increasing the volume of a food by incorporating air affects satiety in men. Am J Clin Nutr 2000;72:361-8. https://doi.org/10.1093/ajcn/72.2.361

20. Leidy H, Carnell N, Mattes R, Campbell W. Higher protein intake preserves lean mass and satiety with weight loss in pre-obese and obese women. Obesity (Silver Spring) 2007;15:421-9. https://doi.org/10.1038/oby.2007.531

21. Lejeune M, Westerterp KR, Adam TC, Luscombe-Marsh ND, WesterterpPlantenga MS. Ghrelin and glucagon-like peptide 1 concentrations, 24h satiety, and energy and substrate metabolism during a high-protein diet and measured in a respiration chamber. Am J Clin Nutr 2006;83:89-94. https://doi.org/10.1093/ajcn/83.1.89

22. Hill A, Blundell J. Macronutrients and satiety: the effects of a high-protein or high-carbohydrate meal on subjective motivation to eat and food preferences. Nutr Behav 1986;3:133-44.

23. Burton-Freeman B. Dietary fibre and energy regulation. J Nutr 2000; 130(2S Suppl):272-5S. https://doi.org/10.1093/jn/130.2.272S

24. Rolls B, Bell E, Thorwart M. Water incorporated into a food but not served with a food decreases energy intake in lean women. Am J Clin Nutr 1999;70:448-55. https://doi.org/10.1093/ajcn/70.4.448

25. Pesta D, Samuel V. A high-protein diet for reducing body fat: mechanisms and possible caveats. Nutr Metab (Lond) 2014;11:53-60. https://doi.org/10.1186/1743-7075-11-53

26. Baba N, Sawaya S, Torbay N, Habbal Z, Azar S, Hashim SA. High protein vs high carbohydrate hypoenergetic diet for the treatment of obese hyperinsulinemic subjects. Int J Obes Relat Metab Disord 1999;23:120206. https://doi.org/10.1038/sj.ijo.0801064

27. Griffioen-Roose S, Mars M, Siebelink E, Finlayson G, Tome D, de Graaf C. Protein status elicits compensatory changes in food intake and food preferences. Am J Clin Nutr 2012;95:32-8. https://doi.org/10.3945/ajcn.111.020503

28. Martens E, Lemmens S, Westerterp-Plantenga M. Protein leverage affects energy intake of high-protein diets in humans. Am J Clin Nutr 2013; 97:86-93. https://doi.org/10.3945/ajcn.112.046540

29. Westerterp-Plantenga M, Luscombe-Marsh ND, Lejeune M, et al. Dietary protein, metabolism, and body-weight regulation: dose-response effects. Int J Obes 2006;30:S16-23. https://doi.org/10.1038/ sj.ijo.0803487

30. Weigle $D$, Breen PA, Matthys CC, et al. A high protein diet induces sustained reductionist in appetite, ad libitum caloric intake, and body weight despite compensatory changes in diurnal plasma leptin and ghrelin concentrations. Am J Clin Nutr 2005;82:41-8. https://doi.org/10.1093/ajcn.82.1.41

31. Skov R, Toubro S, Ronn B, Astrup A. Randomized trial on protein vs carbohydrate in ad libitum fat reduced diet for the treatment of obesity. Int J Obes Relat Metab Disord 1999;23:528-36. https://doi.org/10.1038/sj.ijo.0800867

32. Aller $\mathrm{E}$, Larsen TM, Claus $\mathrm{H}$, et al. Weight loss maintenance in overweight subjects on ad libitum diets with high or low protein content and glycemic index: the DIOGENES trial 12-month results. Int J Obes 2014;38:151117. https://doi.org/10.1038/ijo.2014.52

33. Johnston C, Tjonn S, Swan P. High-protein, low fat diets are effective for 
weight loss and favourably alter biomarkers in healthy adults. $J$ Nutr 2004;134:586-91. https://doi.org/10.1093/jn/134.3.586

34. Simpson $S$, Raubenheimer D. A multi-level analysis of feeding behaviour: the geometry of nutritional decisions. Phil Trans R Soc London Series B: Biol Sci 1993;342:381-402.

https://doi.org/10.1098/rstb.1993.0166

35. Thibault $L$, Booth $D$. Macronutrient-specific dietary selection in rodents and its neural bases. Neurosci Biobehav Rev 1999;23:457-528. https://doi.org/10.1016/s0149-7634(98)00047-5

36. Berthoud H, Münzberg H, Richards B, Morrison C. Neural and metabolic regulation of macronutrient intake and selection. Proc Nutr Soc 2012;71:390-400. https://doi.org/10.1017/S0029665112000559

37. Martinez-Corderoa C. Testing the protein leverage hypothesis in a freeliving human population. Appetite 2012;59:312-5.

38. Rolls $B$, Hetherington $M$, Burley $V$. The specificity of satiety: the influence of foods of different macronutrient content on the development of satiety. Physiol Behav 1988;43:145-53.

39. Simpson S, Batley R, Raubenheimer D. Geometric analysis of macronutrient intake in humans: the power of protein? Appetite 2003;41:123-40.

40. Gosby A, Conjgrave AD, Lau NS, et al. Testing protein leverage in lean humans: a randomized controlled experimental study. PLoS One 2011;6:e25929. https://doi.org/10.1371/journal.pone.0025929

41. Wycherley T, Moran LJ, Clifton PM, Noakes M, Brinkworth GD. Effects of energy-restricted high-protein, low-fat compared with standard-protein, low-fat diets: a meta-analysis of randomized controlled trials. Am J Clin Nutr 2012;96:1281-98. https://doi.org/10.3945/ajcn.112.044321

42. Clifton P, Bastiaans K, Keogh J. High protein diets decrease total and abdominal fat and improve CVD risk profile in overweight and obese men and women with elevated triacylglycerol. Nutr Metab Cardiovasc Dis 2009;19:548-54. https://doi.org/10.1016/j.numecd.2008.10.006

43. Te Morenga L, Levers MT, Williams SM, Brown RC, Mann J. Comparison of high protein and high fiber weight-loss diets in women with risk factors for the metabolic syndrome: a randomized trial. Nutr J 2011;10:40. https://doi.org/10.1186/1475-2891-10-40

44. Astrup A, Raben A, Geiker N. The role of higher protein diets in weight control and obesity-related comorbidities. Int J Obes 2015;39:721-6. https://doi.org/10.1038/ijo.2014.216

45. Esmeijer K, Geleijnse JM, de Fijter JW, Kromhout D, Hoogeveen EK. Dietary protein intake and kidney function decline after myocardial infarction: the Alpha Omega Cohort. Nephrol Dial Transplant 2020;35:106-15. https://doi.org/10.1093/ndt/gfz015

46. Jhee JH, Kee YK, Park S, et al. High-protein diet with renal hyperfiltration is associated with rapid decline rate of renal function: community-based prospective cohort study. Nephrol Dial Transplant 2020;35:98-106. https://doi.org/10.1093/ndt/gfz115

47. Farhadnejad H, Asghari G, Emamat H, Mirmiran P, Azizi F. Low-carbohydrate high-protein diet is associated with increased risk of incident chronic kidney diseases among Tehranian adults. J Renal Nutr 2019;29:343-9. https://doi.org/10.1053/j.jrn.2018.10.007

48. Santesso N, Akl EA, Bianchi M, et al. Effects of higher- versus lowerprotein diets on health outcomes: a systematic review and meta-analysis. Eur J Clin Nutr 2012;66:780-8. https://doi.org/10.1038/ejcn.2012.37

49. Holesh J, Martin A. Physiology, Carbohydrates. [Internet]. StatPearls, 2019. Available from: https://www.ncbi.nlm.nih.gov/books/NBK459280/ (accessed 25 November 2019).

50. Dummies.com. How to calculate your metabolic rate. 2019. Available from: https://www.dummies.com/health/nutrition/how-to-calculate-yourmetabolic-rate/ (accessed 25 November 2019).

51. Statista. Fast food restaurants: most popular 2015. [Online]. 2019. Available from: https://www.statista.com/statistics/527217/leading-fast-foodrestaurants-in-the-united-kingdom-uk/ (accessed 25 November 2019).

52. SELFNutritionData. Fullness FactorTM - NutritionData.com [Internet]. 2019 Available from: https://nutritiondata.self.com/topics/fullness-factor (accessed 25 November 2019).

53. Subway.com [Internet]. 2019. Available from: https://www.subway.com/ en-GB/MenuNutrition/Menu/All (accessed 25 November 2019).

54. mcdonalds.com [Internet]. 2019. Available from: https://www.mcdonalds.com/gb/en-gb/good-to-know/nutrition-calculator.html (accessed 25 November 2019).

55. kfc.co.uk [Internet]. 2019. Available from: https://www.kfc.co.uk/nutrition.pdf (accessed 25 November 2019).

56. Burgerking.co.uk [Internet]. 2019. Available from: https://bk-emeaprd.s3.amazonaws.com/sites/burgerking.co.uk/files/documents/BK191233-UK-NUTRITIONAL-REPORT-A3-F2.pdf (accessed 25 November 2019).

57. Pizzahut.co.uk [Internet]. 2019. Available from: https://www.pizzahut.co.uk/ order/pdfs/Nutritional-Information.78477dd3eb5a16ababfff5be216 bada8.pdf3 (accessed 25 November 2019).

58. fastfoodprice.co.uk [Internet]. 2019. Available from: https://fastfoodprice.co.uk/ (accessed 25 November 2019).

59. burgerlad.com [Internet]. 2019. Available from: https://burgerlad.com/ (accessed 25 November 2019).

60. Nettleton J, Lutsey PL, Wang Y, Lima JA, Michos ED, Jacobs DR Jr. Diet soda intake and risk of incident metabolic syndrome and type 2 diabetes in the multi-ethnic study of atherosclerosis (MESA). Diabetes Care 2009;32:688-94. https://doi.org/10.2337/dc08-1799

61. NHS.UK [Internet]. 5 a day. What counts? 2018. Available from: https://www.nhs.uk/live-well/eat-well/5-a-day-what-counts/ (accessed 25 November 2019).

62. NHS.UK [Internet]. Water, drinks and your health. 2019. Available from: https://www.nhs.uk/live-well/eat-well/water-drinks-nutrition/ (accessed 25 November 2019).

63. Popkin B, D'Anci K, Rosenberg I. Water, hydration, and health. Nutr Rev 2010;68:439-58. https://doi.org/10.1111/j.1753-4887.2010.00304.x

64. Drichoutis AC, Lazaridis P, Nayga RM. Consumers' use of nutritional labels: a review of research studies and issues. Acad Marketing Sci Rev 2006;9:93-118. 


\section{Appendix}

Fullness Factor $=\operatorname{MAX}\left(0.5, \operatorname{MIN}\left(5.0,41.7 / C A L^{\wedge} 0.7+0.05 * P R+6.17 E-4 * D F \wedge 3-7.25 E-6 * T^{\wedge} 3+0.617\right)\right)$

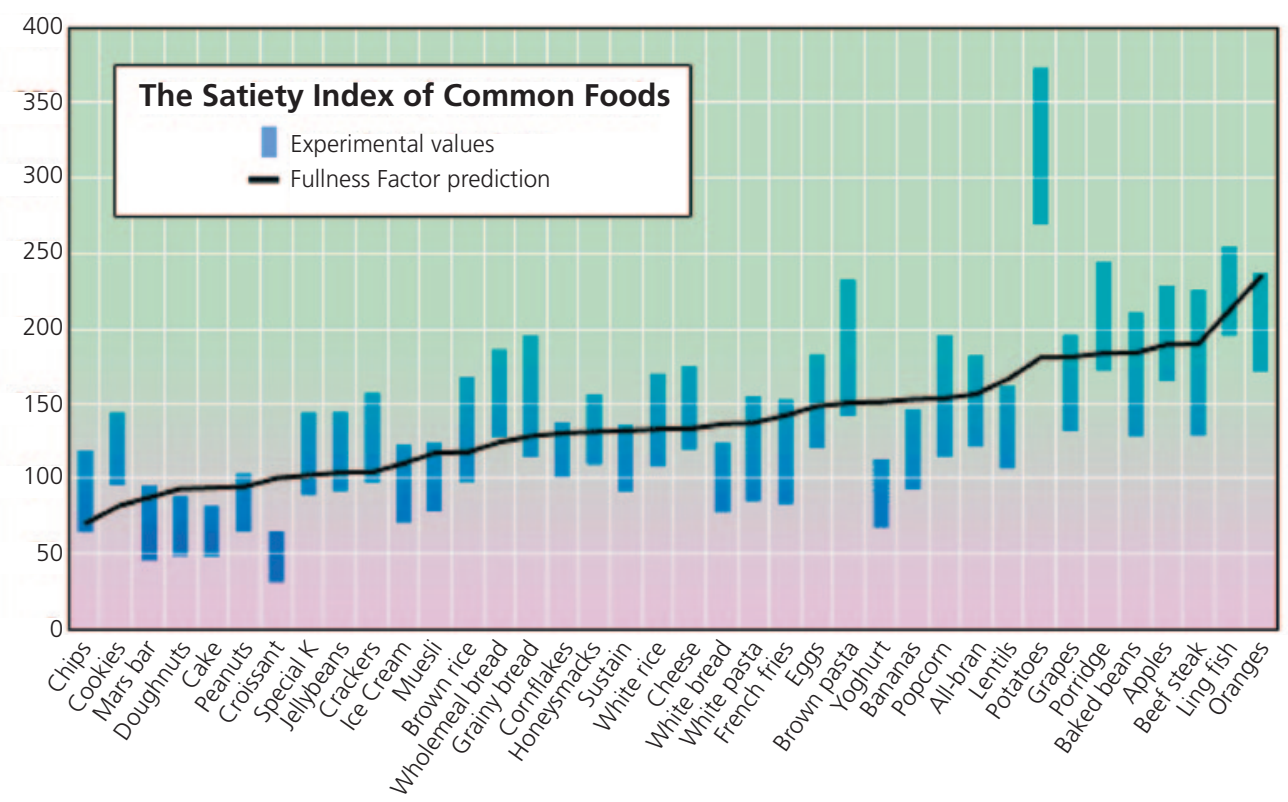

CAL is total Calories per $100 \mathrm{~g}$ (30 minimum)

$\mathrm{PR}$ is grams Protein per $100 \mathrm{~g}$ (30 maximum)

DF is grams Dietary Fibre per $100 \mathrm{~g}$ (12 maximum)

TF is grams total Fat per $100 \mathrm{~g}$ (50 maximum)

This is a measure of satiety produced by company NutritionData using multivariate analysis of results from various satiety studies. Fullness factor gives a value between 0.5 and 5.0, where a higher value indicates a greater level of satiety per calorie.

https://nutritiondata.self.com/topics/fullness-factor

Comparison of fullness factor to the study by Holt et al. ${ }^{18}$

*It is worth noting that, while the fullness factor increases, this is unlikely to translate into a practical improvement in fullness comparing meals of different total calories. This is because fullness factor indicates an increase in satiety per calorie.

Further meal analysis data tables are available upon request: five meals with alternative options analysed for each of the five most popular fast food outlets (25 total tables) 